\title{
THE INTERNET AS A SITE OF LEGAL EDUCATION AND COLLABORATION ACROSS CONTINENTS AND TIME ZONES: USING ONLINE DISPUTE RESOLUTION AS A TOOL FOR STUDENT LEARNING
}

\section{Martha E. Simmons \\ Darin Thompson *}

Increasingly, digital technologies are influencing and impacting dispute resolution, particularly in the emerging field of online dispute resolution (ODR). ODR holds the potential to increase access to justice by engaging disputants in dramatically new ways. As a relatively new subject, ODR is unlikely to form part of the traditional curriculum at law schools. Aside from the question of whether it will become a mainstream part of tomorrow's legal or dispute resolution landscape, ODR does show us that a familiarity with technology is becoming more important for tomorrow's lawyers. As educators, how can we expose law students to these new forces of change in a meaningful way? How can we help students understand the benefits and drawbacks technology holds for the challenge of access to justice? This article describes a unique pilot project of an ODR simulation involving three universities in three cities, two continents, and three time zones. The main objectives of the project were to expose law students to ODR from the perspective of a disputant or client; expose clinical mediation students to a range of technology-based dispute resolution processes; demonstrate the potential for technology to support collaboration across vast distances; and promote experiential education by giving students "hands-on" ODR experience. This article will describe the simulation from an educator's perspective.

Les technologies numériques ont de plus en plus d'influence et de répercussions sur le règlement des différends, surtout dans le nouveau domaine du règlement des conflits en ligne (RCL). Le RCL peut accrô̂tre l'accès à la justice en invitant les parties à adopter des démarches totalement nouvelles. Étant donné qu'il s'agit d'un sujet relativement nouveau, il est peu probable que le RCL soit enseigné dans les écoles de droit traditionnelles. Indépendamment de la question de savoir s'il deviendra éventuellement un élément essentiel de l'environnement de l'exercice du droit ou du règlement des conflits, ce nouveau processus nous montre que les avocats de demain se doivent de bien connaître les technologies. En tant qu'éducateurs, comment pouvons-nous sensibiliser de façon significative les étudiants et étudiantes en droit à ces nouvelles forces de changement? Comment pouvons-nous les aider à comprendre les avantages et les inconvénients que la technologie peut comporter en ce qui a trait à l'accès à la justice? Dans cet article, les auteures décrivent un projet pilote unique de simulation de RCL auquel participent trois

* Martha E Simmons, PhD, Winkler Professor of Dispute Resolution; Director, Mediation Clinic and Intensive Program \& Academic Co-Director, Winkler Institute, Osgoode Hall Law School; Darin Thompson, Legal Counsel, British Columbia Ministry of Justice. This article is based on a blog post initially published on 18 April 2015, online: Legal Technology Education <http://www.lawteched.com/?p=176> and on 23 April 2015, online: Winkler Institute for Dispute Resolution $<$ http://winklerinstitute.ca/experimenting-with-odr-a-law-student-odr-simulation/>. 
universités situées dans trois villes, deux continents et trois fuseaux horaires différents. Le projet visait principalement à faire connaître aux étudiants en droit le mécanisme $d u R C L$ du point de vue d'une partie ou d'un client; à montrer aux clients des cliniques de médiation le fonctionnement d'un éventail de processus de règlement de conflits axés sur la technologie; à démontrer la mesure dans laquelle la technologie peut appuyer la collaboration malgré la distance et à promouvoir l'apprentissage expérimental en permettant aux étudiants d'observer une expérience "directe » en matière de RCL. Dans cet article, la simulation est décrite du point de vue du pédagogue.

\section{INTRODUCTION}

As with much of our world, digital technologies are becoming ubiquitous in law school. Computers are a mainstay in the classroom, in clinics, and in administrative departments. ${ }^{1}$ By now, it is beyond debate that students' legal careers will rely on a fluid understanding of technology to achieve success. ${ }^{2}$ Lawyers are now being urged to "retool" for technology even just to avoid falling behind in our time of rapid change. ${ }^{3}$ Technology is also a significant element in many current initiatives aimed at improving access to justice in the legal systems where tomorrow's lawyers will serve. ${ }^{4}$

Computers are not always welcomed in legal education settings; recent scholarship includes calls for restrictions and outright banishment in the classroom..$^{5}$ Yet, to prepare future lawyers and dispute resolution professionals for a world characterized by technological ubiquity, does it make sense to forego dedicated attempts to provide skills, training, or at least some analysis of computers in the legal curriculum? ${ }^{6}$ Law schools are well positioned to expose students to the potential of the Internet and computers in law and dispute resolution. A foundational understanding in these areas could help students stay relevant in our rapidly accelerating technological landscape once they enter practice. ${ }^{7}$

1 Eric A DeGroff, “The Dynamics of the Contemporary Law School Classroom: Looking at Laptops through a Learning Style Lens" (2014) U Dayton L Rev 201 at 204, online:

$<$ https://udayton.edu/law/_resources/documents/law_review/vol39_no2/the_dynamics_of_the_contemporary_law_schoo 1_classroom.pdf>.

$2 \quad \overline{E g}$, the Florida Supreme Court recently approved a rule requiring practising lawyers to take technology-related continuing legal education courses. See Victor Li, "Florida Supreme Court Approves Mandatory Tech CLE Classes for Lawyers," American Bar Association Journal (30 September 2016), online:

$<$ http://www.abajournal.com/news/article/florida_supreme_court_approves_mandatory_tech_cles_for_lawyers>.

3 Barbara Rose, "No Way Back: Don't Look Now but a Technology Revolution Is Changing the Way Lawyers Work" (2009) 95 ABA J 64.

4 See James E Cabral et al. "Using Technology to Enhance Access to Justice” (2012) 26:1 Harv JL \& Tech 243. Accessto-justice-enhancing technologies like online dispute resolution (ODR) are also being identified to replace traditional court dispute and tribunal dispute resolution processes. See, eg, Lord Justice Briggs, "Civil Courts Structure Review: Final Report," Report for the Judiciary of England and Wales (27 July 2016), online:

$<$ https://www.judiciary.gov.uk/civil-courts-structure-review/civil-courts-structure-review-ccsr-final-report-published/>; see also BC Civil Resolution Tribunal, online: <https:/www.civilresolutionbc.ca/>.

5 Steven M Eisenstat, "A Game Changers: Assessing the Impact of the Princeton/UCLA Laptop Study on the Debate of Whether to Ban Law Student Use of Laptops during Class," Suffolk University Law School Research Paper no 15-4 (2015), online: $<$ http://ssrn.com/abstract=2554535>.

6 Of course, many law schools have been offering some training for students on online legal research databases. But the authors wanted to encourage students and educators to explore functions of the Internet beyond its uses as a form of library for storing, searching, and retrieving information, particularly in the case of new practices like ODR.

7 Richard Susskind \& Daniel Susskind, The Future of the Professions, How Technology Will Transform the Work of Human Experts (Oxford: Oxford University Press, 2015) at 140-141. 
Technologically competent graduates may also have a deeper appreciation of the ways technology can impact access to justice.

This article explores the principles and practical aspects of a pilot project that utilized one stream of technology-based practices in law and dispute resolution, namely online dispute resolution [ODR]. ODR refers to a wide range of processes that use information communication technologies to facilitate dispute resolution. It can encompass a variety of methods and media, with a common feature being that parties are not required to share the same physical space to arrive at resolution. ${ }^{8}$ Consistent with the "online" aspect of ODR, most of its processes are facilitated through the Internet. Some forms of ODR rely on human intervention, while others are automated. ODR can range from the simple day-to-day negotiations via e-mail to complex multi-party video mediations.

Law students rarely receive exposure to ODR, despite its growing use and importance in law and dispute resolution. Law schools tend to emphasize simulations of courtrooms and trials, ${ }^{9}$ paying less attention to emerging technologies that stand to disrupt or even displace traditional law and justice practices. ${ }^{10}$ The 2015 Law Student ODR Project sought to address this gap between the student experience and future practice, particularly with respect to broad questions around the application of technology to dispute resolution, law, and justice. The ODR simulation was an early foray into this new realm of legal pedagogy using technology as a platform for learning and peer-to-peer collaboration across multiple jurisdictions. Exposure to ODR through direct participation encouraged students to form their own impressions about a relatively new, developing area of practice. It also put them in a position to reflect more broadly on the benefits and drawbacks of applying Internet technologies to law and dispute resolution as well as on their relationship to access to justice.

The remainder of this article is organized as follows. In Part II, the subject of ODR will be examined briefly, including an outline of its development, an introduction to some types of the practice, and some consideration of its commonly cited benefits and drawbacks. Part III will offer a description of the student simulation pilot. A selection of brief observations and insights will also be included to identify preliminary results of this pilot project. Part IV will include some recommendations for future directions and research and a general conclusion.

\section{AN INTRODUCTION TO ODR}

In this section, a brief description of ODR, including its development, its nature, and its benefits and drawbacks is provided for readers who lack familiarity with this new form of technology-based dispute resolution. While the subject of ODR is analyzed and explained in a growing body of literature, ${ }^{11}$ this brief discussion is offered primarily to provide context for the student simulation.

8 Department of Justice Canada, “Online Dispute Reference Guide” (2012) at iii, online: <http://www.justice.gc.ca/eng/rp$\mathrm{pr} / \mathrm{csj}$-sjc/dprs-sprd/res/drrg-mrrc/10.html\#iii >.

9 See Stacy Burns, "Practicing Law: A Study of Pedagogic Interchange in a Law School Classroom" in Max Travers \& John F Manzo, eds, Law in Action: Ethnomethodological and Conversation Analytic Approaches to Law (New York: Routledge, 1997) at 265.

10 Michelle Pistone \& Michael B Horn, "Disrupting Law School: How Disruptive Innovation Will Revolutionize the Legal World," White Paper for the Clayton Christensen Institute (15 March 2016) at 6.

11 Early leading works include Ethan Katsh \& Janet Rifkin, Online Dispute Resolution: Resolving Disputes in Cyberspace (San Francisco: Jossey-Bass, 2001); Colin Rule, Online Dispute Resolution for Business: B2B, ECommerce, Consumer, Employment, Insurance, and Other Commercial Conflicts (San Francisco: Jossey-Bass, 2002). More recent literature is available in Mohamed Abdel Wahab, Ethan Katsh \& Daniel Rainey, eds, Online Dispute Resolution: Theory and Practice - A Treatise on Technology and Dispute Resolution (The Hague: Eleven, 2012); International Journal of Online Dispute Resolution (The Hague: Eleven, 2014). 


\section{A. A Brief History of ODR}

Beginning in the late 1990s, ODR began to emerge as a new technique for resolving disputes that arose online. ${ }^{12}$ The rise of the electronic marketplace, filled with online shoppers from around the globe, engaging in high volumes of low value transactions, required mechanisms to manage disputes that could not be accommodated by traditional, offline fora like courts or other face-to-face resolution processes. ${ }^{13}$ The Internet offered a new virtual place where dispute resolution could occur through the development of ODR. From its origins as a relatively experimental concept for dispute resolution in the new e-commerce environment, ODR quickly developed into a more mainstream mechanism for different kinds of disputes. $^{14}$

The well-known online marketplace eBay was a pioneer in ODR, using it to address disputes for unhappy consumers. ${ }^{15}$ The eBay ODR program began as a pilot project in partnership with the University of Massachusetts Amherst Center for Information Technology, facilitating the resolution of 200 disputes a week in 1999. ${ }^{16}$ By 2010, the eBay system was reported to be handling 60 million disputes annually. ${ }^{17}$ Obviously, traditional dispute resolvers would be unable to cope with this new breed of consumer disputes, just on the basis of volume. Given that Internet-based purchases often cross borders (and legal systems), it becomes almost imperative that the dispute resolution process also do the same. From a design perspective, ODR could address this need in the online commercial marketplace. ${ }^{18}$

International bodies and organizations are working to incorporate ODR platforms into their justice systems. For example, the European Union [EU] issued a directive and an accompanying regulation to launch a consumer online dispute resolution program to manage disputes across the single market arising from online transactions. ${ }^{19}$ The initiative included the creation of an ODR platform to provide consumers and sellers with improved access to non-court forms of dispute resolution. ${ }^{20}$ The United Nations Commission on International Trade Law [UNCITRAL] also attempted to create a set of model ODR rules for resolving cross-border consumer transactions. ${ }^{21}$ In common with the EU initiative, a principle objective for the UNCITRAL effort was to provide consumers with a new form of redress for cross-border consumer disputes, particularly since the speed of online transactions, combined with the costs and complexity of court for lower-value transactions, often put traditional sources of dispute resolution out of

12 Ethan Katsh, "ODR: A Look at History: A Few Thoughts about the Present and Some Speculation about the Future" in Wahab, Katsh \& Rainey, supra note 11 at 22-24.

13 Ibid at 21

14 In 1998, Robert Bordone noted: "[I]n an ideal world, the dispute resolution model of Cyberspace may become so attractive that real world disputants might be moved to take their disputes online for resolution." Robert C Bordone, "Electronic Online Dispute Resolution: A Systems Approach - Potential Problems, and a Proposal" (1998) 3 Harv Negot L Rev 175.

15 Katsh, supra note 12 at 27; Dusty Bates Farned, “A New Automated Class of Online Dispute Resolution: Changing the Meaning of Computer-Mediated Communication” (2011) 2 Faulkner L Rev 335.

16 Katsh, supra note 12 at 27.

17 Ibid at 27.

18 Scott Cooper, Colin Rule \& Louis Del Duca, "From Lex Mercatoria to Online Dispute Resolution: Lessons from History in Building Cross-Border Redress Systems" (2011) 43(3) Unif Comm Code L J 13.

19 European Commission, "Alternative and Online Dispute Resolution," online: $<$ http://ec.europa.eu/consumers/solving_consumer_disputes/non-judicial_redress/adr-odr/index_en.htm $>$. The ODR platform can be accessed at $<$ https://webgate.ec.europa.eu/odr/main/index.cfm?event=main.home.chooseLanguage $>$.

20 European Commission, "Solving Disputes Online: New Platform for Consumers and Traders," Press Release (15 February 2016), online: <http://europa.eu/rapid/press-release_IP-16-297_en.htm>.

21 United Nations Commission on International Trade Law (UNCITRAL), "2010-2016: Online Dispute Resolution," online: <http://www.uncitral.org/uncitral/commission/working_groups/3Online_Dispute_Resolution.html >. 
reach. ${ }^{22}$ In this regard, access to justice was a strong undercurrent in the initiative. While the UNCITRAL effort did not result in a complete set of model rules, it did produce a document attempting to explain the elements and principles of a cross-border ODR system. ${ }^{23}$ These internationally focused initiatives demonstrate an attempt to leverage ODR as a means to increase access to justice for consumers.

ODR is also gaining a foothold in domestic justice systems, both for online and offline disputes. For example, an administrative tribunal in the province of British Columbia, Canada, adopted ODR technology to manage property assessment appeals online, beginning in $2011 .^{24}$ Since then, several jurisdictions in the United States have implemented similar systems. ${ }^{25}$ In 2012 , British Columbia became the first Canadian jurisdiction to codify ODR into its body of laws, with the passage of the Civil Resolution Tribunal Act. ${ }^{26}$ The tribunal created by this legislation began operations for condominium disputes in July $2016,{ }^{27}$ with small claims disputes added to its jurisdiction in $2017 .^{28}$ From a design perspective, British Columbia's online tribunal stands to prove the efficacy of ODR as a means to resolve disputes that arise outside e-commerce and, presumably, outside of the Internet altogether. It could also prove the potential of ODR to increase access to justice. ${ }^{29}$

Outside British Columbia, other Canadian provinces have also begun to consider ODR. For example, Ontario has considered it for handling minor provincial offences. ${ }^{30}$ As revealed by Brendan Crawley, spokesperson for the Ministry of the Attorney General in Ontario,

[the ministry] is in the early stages of considering [ODR] for a number of ministry programs. It has potential application for resolving not only court disputes but also some kinds of disputes in administrative tribunals, as well as for taking some of those disputes out of the public system entirely. ${ }^{31}$

22 United Nations, "Report of the United Nations Commission on International Trade Law, Forty-third session," Doc A/65/17 (21 June - 9 July 2010) at 51 .

23 UNCITRAL, "Online Dispute Resolution for Cross-Border Electronic Commerce Transactions: Draft Outcome Document Reflecting Elements and Principles of an ODR Process," Note by the Secretariat (22 December 2015).

24 Julius Melnitzer, "Move towards Online Dispute Resolution Gathers Steam," LawTimes (2 March 2015), online: $<$ http://www.lawtimesnews.com/201503024521/headline-news/move-towards-online-dispute-resolution-gathers-steam>; Darin Thompson, "The Growth of Online Dispute Resolution and Its Use in British Columbia," Continuing Legal Education Society of British Columbia - Civil Litigation Conference Paper (2014) at para 1.1.4. [Thompson, "Growth of Online Dispute Resolution"].

25 Robert Ambrogi, “Tax Boards Use an Online System to Resolve Disputes," American Bar Association Journal (1 March 2015), online: $<$ http://www.abajournal.com/magazine/article/tax_boards_use_an_online_system_to_resolve_disputes/>.

26 SBC 2012, c 25, s 1, on the definition of "online dispute resolution services."

27 Darin Thompson, "The Online Justice Experience in British Columbia," Society for Computers and Law (22 November 2016), online: $<$ https://www.scl.org/articles/3784-the-online-justice-experience-in-british-columbia >.

28 Shannon Salter, "The Civil Resolution Tribunal's Next Steps," Canadian Bar Association - Bar Talk (1 February 2017), online: <http://www.cbabc.org/BarTalk/Columns/Guest-Column/The-Civil-Resolution-Tribunal\%E2\%80\%99s-NextSteps $>$.

29 Ian Mulgrew, "B.C. Launches First-in-Canada Online Tribunal to Resolve Civil Disputes," Vancouver Sun (15 July 2016), online: $<$ http://vancouversun.com/news/local-news/b-c-launches-first-in-canada-online-tribunal-to-resolve-civildisputes $>$.

30 Ontario Ministry of the Attorney General, "Exploring an Online Administrative Monetary Penalty System for Infractions of Provincial Statutes and Municipal By-laws in Ontario," Consultation Paper (3 March 2015), online:

$<$ https://www.attorneygeneral.jus.gov.on.ca/english/POA\%20ConsultationPaper\%20Final_ENG.html>.

31 Quoted in Julius Melnitzer, "Move toward Online Dispute Resolution Gathers Steam," Law Times News (2 March 2015), online: <http://www.lawtimesnews.com/201503024521/headline-news/move-towards-online-dispute-resolution-gatherssteam $>$. 
In England and Wales, the judiciary is leading a review that includes a proposal to include an entirely new division of online courts. ${ }^{32}$ In terms of the legitimacy and use of ODR, it is significant that the birthplace of the common legal system is making a strong commitment to create a new branch of courts using the Internet. It is also illuminating to consider the link between ODR and access to justice. As Lord Dyson, Master of the Rolls, observes:

There is no doubt that online dispute resolution (ODR) is an area with enormous potential for meeting the needs of the system and its users in the $21^{\text {st }}$ Century. Its aim is to broaden access to justice and resolve disputes more easily, quickly and cheaply. The challenge lies in delivering a system that fulfils that objective. ${ }^{33}$

Some ODR initiatives operate alongside the public justice system in a complementary way. For example, online divorce platforms based on a combination of the Dutch Rechtwijzer platform and the Modria dispute resolution platform are now in use in the Netherlands and British Columbia. ${ }^{34}$ The United Kingdom's Resolver ODR platform provides a relatively straightforward process for consumers to raise complaints and then to potentially resolve them online with a retailer. ${ }^{35}$ In British Columbia, the Consumer Protection BC ODR process also caters to disputes between consumers and retailers. ${ }^{36}$ Technology will likely continue to play a significant role in efforts to increase access to justice. As stated by the Action Committee on Access to Justice in Civil and Family Matters, "[t]he key justice system stakeholders in each Province and Territory should collaborate to explore and realize the access to justice benefits of webbased legal services and on-line dispute resolution models.",37

Practices like ODR do more than merely automate existing processes in an attempt to increase access; they often seek to change them fundamentally. The Courts of England and Wales' Civil Justice Council Working Group on ODR emphasized the transformative potential for ODR not just to streamline conventional dispute resolution in the courts but also to embrace a broader access-to-justice philosophy that includes an entirely new justice architecture. ${ }^{38}$ ODR is therefore a potentially strong example of a field that stands to increase access to justice and change the business of law and justice in the process. As evidenced by this brief account of its development, ODR is becoming part of the legal and justice context in many jurisdictions. With multiple examples of ODR directly within British Columbia's justice system, Canada is uniquely positioned to emerge as a leader in this field. With access to local ODR expertise,

32 Lord Justice Briggs, "Civil Courts Structure Review: Interim Report,” Interim Report on the Civil Courts Structure Review commissioned by the Lord Chief Justice and the Master of the Rolls (December 2015) at 75-87, online: $<$ https://www.judiciary.gov.uk/wp-content/uploads/2016/01/CCSR-interim-report-dec-15-final-31.pdf>; Civil Justice Council, "Online Dispute Resolution for Low Value Civil Claims," Online Dispute Resolution Advisory Group (February 2015), online: <https:/www.judiciary.gov.uk/wp-content/uploads/2015/02/Online-Dispute-Resolution-FinalWeb-Version1.pdf>.

33 Ibid at 2.

34 Carol Matlack, “Robots Are Taking Divorce Lawyers’ Jobs, Too,” Bloomberg Businessweek (30 June 2016), online: $<$ https://www.bloomberg.com/news/articles/2016-06-30/robots-are-taking-divorce-lawyers-jobs-too>.

35 Civil Justice Council, supra note 32 at 14.

36 Thompson, "Growth of Online Dispute Resolution," supra note 24 at para 1.1.4. Visit the platform's website at $<$ https://www.consumerprotectionbc.ca/odr>.

37 Alison MacPhail, Action Committee on Access to Justice in Civil and Family Matters, "Report of the Access to Legal Services Working Group" (2012) at 15, online: <http:/www.cfcjfcjc.org/sites/default/files/docs/2012/Report\%20of\%20the\%20Access\%20to\%20Legal\%20Services\%20Working\%20Gr oup.pdf $>$.

38 Civil Justice Council, supra note 32 at $17-18$. 
Canadian law schools are well positioned to introduce ODR into the legal curriculum, even if only through experimental pilot projects like the one described in this article. If we are to prepare law students for the world they are likely to encounter in practice, ODR should be considered as an additional unit of study and practice in the law school curriculum. At minimum, the study of ODR exposes students to the application of technology to legal practice and dispute resolution, with an emphasis on increasing access to justice.

\section{B. Examples of ODR Processes}

An expansive range of processes can be considered under the heading of ODR. Defined broadly, it involves the application of information communication technologies - typically the Internet and e-mail to dispute resolution processes. ${ }^{39}$ In this way, the Internet becomes a substitute for courtrooms, negotiation tables, and mediation rooms. ODR can thus provide a new platform to complement or supplant other tools and places for dispute resolution. Some of its advantages relate to the fact that the Internet is itself a fast, affordable, and effective tool for creating, sharing, searching, and retaining information. ${ }^{40}$ These functions could be considered the core activities in most dispute resolution processes.

In practice, ODR can be as simple as negotiation via text-based, Internet communications such as email. ODR's communication media can also include instant messaging, online chats, threaded discussions, recorded video and audio streams, and video conferencing. ${ }^{41}$ ODR systems often rely on web-based platforms that facilitate communications and the exchange of other information between parties. Interactions between parties may be facilitated by a neutral human third party or by software alone. This section will provide examples of some different forms of ODR in order to place the different aspects of the student simulation in context with ODR more generally. While a complete survey of ODR types is not included here, this section seeks to provide the reader with a broad overview for contextual purposes.

\section{Automated Negotiation}

Some ODR platforms focus primarily on the exchange of numerically based demands and offers between parties. Often called blind-bid negotiation, these processes allow each party to submit an offer without knowing what the opponent party is demanding or offering. ${ }^{42}$ The person in the role of a claimant can initiate the process and make a demand for a specific dollar amount in the ODR platform representing the terms upon which that claimant is prepared to settle. The opponent party can then make an offer in an amount to settle. The ODR platform can compare demands and offers to search for the overlap between the figures that would suggest a settlement. ${ }^{43}$ Depending on the platform, the software may split the difference between any overlap or adjust it in favour of one party or another and determine the final settlement amount. ${ }^{44}$ The parties would then be notified of the settlement, with the determined amount representing the terms of agreement resolving the dispute. If there is no overlap between the demand and

39 Thompson, "Growth of Online Dispute Resolution," supra note 24 at para 1.1.1.

$40 \quad$ Ibid at paras 1.1.1-1.1.2.

41 Ibid.

42 Susan van Arsdale, "User Protections in Online Dispute Resolution," (2015) 21 Harv Negot L Rev 107 at 113.

43 Ibid at 113; Joseph W Goodman, "Pros and Cons of Online Dispute Resolution: An Assessment of Cyber-Mediation Websites" (2003) Duke L \& Tech Rev 3.

44 Clive Thompson, "Double Blind: Negotiating on the Internet Gets Lawyers' Egos Out of the Way," Legal Affairs (May/June 2004), online: <https://www.legalaffairs.org/issues/May-June-2004/scene_thompson_mayjun04.msp>. 
offer, the blind-bid platform can be configured to allow subsequent rounds of new offers and counteroffers, ${ }^{45}$ with the expectation that the parties will gradually move closer to one another in dollar amount. ${ }^{46}$

The blind-bid process does not require a human neutral third party; the computer software functions instead in this role. ${ }^{47}$ The ODR platform will drive the process by doing things like inviting parties to make offers and demands or alerting them to the emergence of a settlement. Of course, the ODR platform's role is quite limited in a simple blind-bid system, making it suitable for some disputes, such as ecommerce, and less appropriate for complicated interest-based disputes or interpersonal conflicts. Rather than a weakness, the creation of a simple process for simple types of disputes may be its strength, at least with respect to efficiency. As stated by Orna Rabinovitch-Einy, "direct negotiation technology is a much more efficient means for resolving simple disputes than relying on a human mediator."

This type of ODR is designed to be economical, from both a cost and time perspective. It not only encourages, but also forces, the parties to focus strictly on a dollar amount to settle the dispute. It can facilitate the negotiation across any distance and without the parties having to even speak with each other. However, some parties may find it quite difficult to focus only on the dollar amount. Even if they are not exploring the possibility of an apology or explanation for some perceived wrong or harm, they might at least want to know the basis of how the other side calculated their demand or offer. In fact, agreeing that the dispute resolution process will focus only on the determination of a settlement amount is a prerequisite to the process. ${ }^{49}$

\section{Asynchronous Text-Based Negotiation}

Some ODR processes feature asynchronous text-based negotiation. In this approach, the ODR platform will support the exchange of text-based information and communications via the Internet. ${ }^{50}$ This exchange is asynchronous because the communications will not happen simultaneously as they would in a real-time conversation. Rather, it happens at different times, often within a specific period. ${ }^{51}$ For example, one disputant may make a demand of the other party via text-based messages through an ODR platform. Several minutes, hours, or even days later, another party may receive and review the demand and then provide a counter-offer or new demand. The party who made the first demand could then retrieve this response from the platform and continue the process by making a subsequent demand or counter-proposal. Over time, this exchange of communications forms the basis of an asynchronous negotiation. ${ }^{52}$

While an asynchronous text-based negotiation may seem deficient to negotiators in comparison with face-to-face meetings and oral exchanges, it is less controversial when we consider that e-mail has already become one of our most common and heavily utilized modes of communication. Especially with the advent of smart phones, e-mails can be sent and received from anywhere at any time. When people attempt to resolve disputes through these e-mails, they are effectively participating in ad hoc ODR processes. These negotiations happen throughout the world on a regular basis and often include legal subject matter,

45 Van Arsdale, supra note 42 at 113.

46 Thompson, supra note 44.

47 Orna Rabinovich-Einy \& Ethan Katsh, "Lessons from Online Dispute Resolution for System Design" in Wahab, Katsh \& Rainey, supra note 11, 53.

48 Orna Rabinovitch-Einy, "Balancing the Scales: The Ford-Firestone Case, the Internet, and the Future of the Dispute Resolution Landscape" (2003-2004) 6 Yale JL \& Tech 30.

49 Lucille M Ponte, "Throwing Bad Money after Bad: Can Online Dispute Resolution (ODR) Really Deliver the Goods for the Unhappy Internet Shopper?” (2001) 3 Tul J Tech \& Intellectual Property 79.

50 Goodman, supra note 43.

51 Ibid at 8 .

52 Karolina Mania, "Online Dispute Resolution: The Future of Justice” (2015) Intl Comp Juris 79. 
whether it is between lawyers on behalf of clients, between an insured person and his or her insurer, or between a buyer and seller over a consumer contract issue. In this respect, asynchronous text-based ODR is arguably a common dispute resolution practice already.

Rather than rely exclusively on e-mail, many asynchronous text-based ODR processes use web-based discussion-style boards that record and display dispute-related information and communications in a secure platform. ${ }^{53}$ When one party submits something to the ODR platform, it may send a notification to the opponent parties, alerting them to log into the system so they can review it and respond. ${ }^{54}$ In law school, our tendency might be to prepare students to exchange formally written court pleadings or demand letters, neither of which are remotely associated with ordinary communication forms in the present day. By using digital forms of interactions, the simulation brought the potential to demonstrate new ways to communicate in the legal sphere using methods that were already in heavy use among law students and their future clients.

\section{Online Facilitation and Mediation}

The text-based negotiation ODR approach can also accommodate third party neutrals, including mediators and decision makers. ${ }^{55}$ These neutrals can interject themselves into the resolution process by sending their own communications, either to all parties at once or to individual parties in an online "caucus" approach, if the ODR platform allows for it. ${ }^{56}$ Facilitated ODR processes can also include realtime audio and video interactions using video-conferencing technologies. ${ }^{57}$ While this approach differs in in-person mediation processes, it can import certain aspects of face-to-face interactions for disputants and neutrals without the need to be physically present in the same room.

\section{Benefits and Drawbacks of ODR}

ODR is a subject that can polarize lawyers, academics, and dispute resolution practitioners. Some see it as a promising response to many of today's pressures in the areas of justice and dispute resolution, ${ }^{58}$ while others approach the subject with considerably less enthusiasm. ${ }^{59}$ A sampling of commonly cited benefits and drawbacks is included here to highlight the observations students in the ODR simulation might make through an experiential learning exercise.

A commonly cited benefit of ODR is its potential to make physical space and distance less significant or important. ${ }^{60}$ Disputants can participate in ODR and resolve their disputes from any location through a device with Internet connectivity. Drawing on the speed and accessibility of Internet-based communications, ODR can support dispute resolution across vast distances, allowing a person to resolve a dispute with someone in another country without having to leave home. ${ }^{61}$ Even where disputants are not separated by great distance, ODR can eliminate the time, cost, and inconvenience associated with

53 Ponte, supra note 49 at 75.

$54 \quad$ Ibid at 77.

55 Mania, supra note 52 at 78-82; see also Ponte, supra note 49 at 79-86.

56 Goodman, supra note 43 at 8.

57 Mania, supra note 52 at 79.

58 See eg, Civil Justice Council, supra note 32.

59 See Kathryn Thomson, “Are Online Dispute Resolution Processes Necessarily Access to Justice Strategies?” Slaw: Canada's Online Legal Magazine (15 April 2014), online: <http://www.slaw.ca/2014/04/15/are-online-disputeresolution-processes-necessarily-access-to-justice-strategies/>; Colin Rule, "Technology and the Future of Dispute Resolution," Dispute Resolution Magazine (Winter 2015) at 5-6.

60 Rabinovich-Einy \& Katsh, supra note 47 at 51-52.

61 In these situations, there can still be challenges around jurisdictional differences and applicable law as well as differences in time zones, language, and culture. 
scheduled court appearances or other in-person processes. A disputant with a regular job will not have to take time off work and travel to a dispute resolution process. As a remote form of interaction, ODR can also capitalize on the physical separation of the parties in other ways. For example, parties involved in a high-conflict dispute can engage in a resolution process without the added tension and stress of being physically present in the same room. ${ }^{62}$

Asynchronous ODR processes can also reduce or eliminate temporal challenges. If the disputing parties can interact asynchronously, it increases convenience in terms of scheduling and party availability. ${ }^{63}$ Disputants can participate when they are ready and at a pace that suits them. ${ }^{64}$ In contrast with real-time, face-to-face interactions, they will have time to think about their communications, draft and redraft them to express a particular point or tone, and deliver them when they are ready. Parties could even take time to consult with a lawyer or another person for guidance before making each interaction. The elimination of physical, geographical, and temporal restrictions contributes to an overall reduction in the expense associated with dispute resolution. Reliance on the Internet as a platform makes ODR an economical method for resolving disputes. ${ }^{65}$ In an age where the cost of civil dispute resolution is making it too expensive for many people to resolve their disputes, ${ }^{66}$ cost reductions can significantly increase access to justice. Parties using ODR will not have to travel by plane to a distant city nor by bus, train, car, or taxi to their local courthouse.

ODR processes like automated negotiation can significantly reduce human involvement for the person or organization administering the process, resulting in further efficiencies. As Ethan Katsh and Colin Rule note, ODR has "made it possible for extraordinarily large numbers of disputes to be handled at very low cost, removing the problem of capacity and price associated with a human third party decision-maker or facilitator." ${ }^{\text {, }}$ While the automation of the third-party role may not be suitable in every case, its scalability can result in significant benefits for appropriate dispute types. ${ }^{68}$

Despite these proclaimed benefits of ODR, it is the subject of criticism on several fronts, the most significant of which may relate to its core dependence on digital technologies. Accessing technologies that connect to the Internet can be a challenge for some disputants, particularly in the case of marginalized groups and people unaccustomed to using technology. ${ }^{69}$ The scale of this so-called digital divide is relatively small and appears to be shrinking. A recent Statistics Canada report revealed that "83 per cent of Canadian households had access to the Internet at home," an increase from 79 percent in $2010 .^{70}$ Indeed, a Canadian Internet Registration Authority report indicated that by 2014, 87 percent of Canadian

62 Noam Ebner, “e-Mediation” in Wahab, Katsh \& Rainey, supra note 11, 377.

63 Goodman, supra note 43 at 8.

64 Ibid at 8 .

65 Ibid at 7. See, eg, Martin Gramatikov, ed, Costs and Quality of Online Dispute Resoluton: A Handbook for Measuring the Costs and Quality of ODR (Antwerpen: Maklu, 2012); Civil Justice Council, supra note 32 at 8.

66 See eg, Noel Semple, “The Cost of Seeking Civil Justice in Canada” (2016) 93:3 Can Bar Rev 639 at paras 2-4, online: $<$ https://ssrn.com/abstract $=2616749>$.

67 Ethan Katsh \& Colin Rule, "What We Know and Need to Know about Online Dispute Resolution" (2016) 67:329 SCL Rev 330.

68 The commonly cited example illustrating this point is eBay's ODR system, which is said to have resulted in an $80 \%$ resolution rate for the 60 million disputes it was handling annually. See Rabinovich-Einy \& Katsh, supra note 47 at 54.

69 Carrie Menkel-Meadow, "Is ODR ADR? Reflections of an ADR Founder from 15th ODR Conference, the Hague, the Netherlands, 22-23 May 2016" (2017) 3:1 Intl J Online Dispute Resolution 4.

70 Statistics Canada, "Canadian Internet Usage Survey, 2012" (28 October 2013), online: $<$ http://www23.statcan.gc.ca/imdb/p2SV.pl?Function=getSurvey\&SDDS=4432>. 
households were connected to the Internet. ${ }^{71}$ One province reported daily Internet usage rates as high as 92 percent of the citizens surveyed. ${ }^{72}$ However, even if the scale is small, the impact or significance for those affected is significant. Of those that reported no Internet access in their homes in the Statistics Canada report, 61 percent indicated that they had no need for Internet technology, with 20 percent reporting cost as the reason. ${ }^{73}$ Some users may simply have a strong aversion to the Internet and associated technologies, while others lack the resources to use it regardless of personal preference. In any event, the digital divide continues to be a challenge for ODR, even if the number of affected people is relatively small.

Another practical criticism of ODR relates to modes of communication. The forms of human interaction we typically associate with dispute resolution may be absent or altered significantly. At its core, this argument asserts that interactions through digital modes of communication are inferior to faceto-face communications. ${ }^{74}$ Others point out that the altered forms of communication in ODR processes can have a negative impact on the element of trust in dispute resolution. ${ }^{75}$ ODR processes can significantly reduce or eliminate non-verbal communication that some dispute resolution practitioners consider to be important. $^{76}$ Non-verbal cues may be present in ODR processes using video conferencing, but the depersonalizing effect of technology as a conduit can nevertheless diminish or alter the significance of unspoken communication. $^{77}$ In text-based communication processes, there is neither verbal communication nor the same types of cues present in a face-to-face engagement. Research on text-based asynchronous communication in dispute resolution does suggest some apparent weaknesses in text-based asynchronous communication with respect to the process. ${ }^{78}$

Dispute resolution practitioners who have learned their craft through a body of knowledge focused primarily on face-to-face communication methods should almost be expected to find unspoken interactions or verbal cues important to their success. ${ }^{79}$ However, one online mediation simulation suggested that dispute resolution practitioners' concerns over the absence of face-to-face communication were not actually shared by the disputants. ${ }^{80}$ Within the larger field of dispute resolution, ODR's limitations could be attributed to a lack of understanding and expertise. It might also be the subject of cultural opposition from dispute resolution professionals with years of training and experience in more traditional offline practices. The apparent differences between ODR and offline forms of dispute resolution tend to be exaggerated by a dichotomous approach to the subject of technology and the way it may be incorporated into the process. Many arguments imply that an ODR process can utilize only one form of digital communication, rather than multiple forms. While the creation of this dichotomy is

71 Canadian Internet Registration Authority, "The Canadian Internet," online: $<$ https://cira.ca/factbook/current/thecanadian-internet.html>.

72 Lisa Nakamura, "New Survey Results: British Columbia is Online" (29 September 2015), online: $<$ https://www.civilresolutionbc.ca/new-survey-results-british-columbia-is-online/>.

73 Ibid.

74 Goodman, supra note 43 at 9.

75 See Noam Ebner, “ODR and Interpersonal Trust” in Wahab, Katsh \& Rainey, supra note 11, 215.

76 Goodman, supra note 43 at 9.

77 Ibid at $10-11$.

78 See, eg, SN Exon, "Maximizing Technology to Establish Trust in an Online, Non-Visual Mediation Setting” (2011) 33 U La Verne L Rev 27; Noam Ebner, "Trust-building in E-negotiation" in L Brennan \& V Johnson, eds, ComputerMediated Relationships and Trust: Managerial and Organizational Effects (Hershey, PA: Information Science Publishing, 2007).

79 Ebner, supra note 62 at 388.

80 Anne-Marie Hammond, "How Do You Write 'Yes'?: A Study on the Effectiveness of Online Dispute Resolution" (2003) 20 Conflict Resolution Q 277. 
potentially helpful in the abstract as an argumentative technique, it does not reflect reality with respect to the way we communicate. People are mixing technology and non-technology-based interactions in many aspects of our lives, and dispute resolution is no exception. ${ }^{81}$ From a dispute resolution system design perspective, alternative dispute resolution may be adapting itself to ODR, while ODR may be moving through the stages of becoming an accepted, trusted tool for practitioners. ${ }^{82}$

From a pedagogical perspective, the simulation provided an opportunity for students to form their own opinions about ODR's benefits and drawbacks. Students had a chance to frame their opinions based on real-world experiences rather than on having to rely on a synthesis of opinions advanced by authors and other commentators, many of whom may never have tried ODR themselves. We sought to provide handson experience with ODR and to encourage students to draw their own conclusions and engage directly with broader questions about its suitability in the field of dispute resolution and its potential impact on access to justice. Empowered with this level of knowledge and experience, these students may go on to shape the future of ODR, whether they are for it or against it.

To a lesser extent, the ODR simulation pilot project created opportunities for law students to engage in new types of learning. Many of the participants were playing the role of disputant, experiencing some of the challenges and concerns their future clients might experience. Clinical mediation program students had an opportunity to play the role of a neutral in a simulated dispute. These neutrals were likely among the first students in any law school to apply technology to the dispute resolution process as relative newcomers to the field before they developed strong preferences for face-to-face interactions or biases against technology-facilitated interactions. The pilot project also used technology as a platform for colearning and collaboration with students from other law schools in other time zones and countries. As instructors, we felt these experiments could apply quite broadly in the context of legal education, well beyond the topic of ODR.

\section{DESCRIPTION OF THE ODR SIMULATION}

To this point, this article has outlined ODR's development and its characteristics. In this section, we provide a description of the simulation that is the subject of this article. This description will explain the three distinct types of ODR that were included in the simulation. Some observations of the simulation's results will also be included.

\section{A. Simulation Overview}

The simulation was inspired by the idea that students could gain insights and develop opinions about ODR by experiencing it through a series of simulated exercises. The 2015 Law Student ODR Project ran from early February to early March 2015. The project was a collaborative exercise involving three universities in two countries, two continents, and three time zones. The main objectives of the project were to:

- expose law students to ODR from the perspective of a disputant or client;

- expose clinical mediation students to a range of technology-based dispute resolution processes;

- demonstrate the potential for technology to support collaboration across vast distances; and

81 Rule, supra note 59 at 6.

82 Rabinovich-Einy \& Katsh, supra note 47 at 86. 
- promote experiential education by giving students "hands-on" ODR experience paired with discussion and reflection.

The project involved the following participants: twenty clinical mediation program students and seventeen legal information technology students from Osgoode Hall Law School, ${ }^{83}$ part of York University, in Toronto, Canada; nine legal information technology students from the Faculty of Law at the University of Victoria ${ }^{84}$ in Victoria, Canada; nine law students from the University of Leicester in Leicester, England; two faculty members from the University of Leicester ${ }^{85}$ in Leicester, England; one faculty member from Osgoode Hall Law School in Toronto, Canada; two representatives from British Columbia's first public tribunal to use ODR - the Property Assessment Appeal Board, ${ }^{86}$ located in Richmond, Canada; two public servants from the government of British Columbia, ${ }^{87}$ located in Victoria, Canada; and two more who served as "spares" who would step in and take the place of another disputant if necessary) (Figure 1).

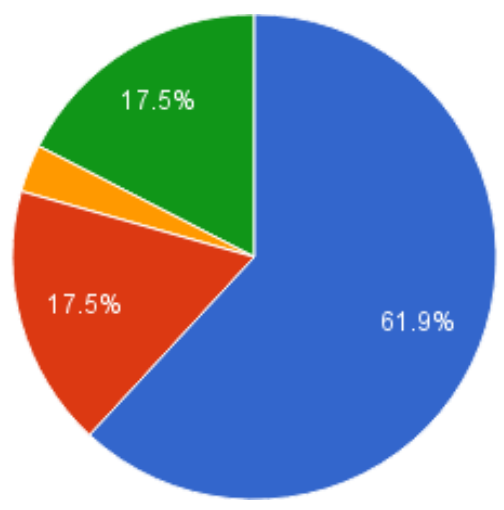

Toronto, Canada (UTC-05:00)

Leicester, England (UTC+00:00)

Vancouver, Canada (UTC-08:00)

Victoria, Canada (UTC-08:00)

Figure 1: Participants by Location

The project centred around nineteen to twenty individual disputes, consisting of two role-playing parties and one facilitator/mediator for each. ${ }^{88}$ Each disputant received fact patterns for their respective roles in the simulation, including confidential role-based instructions. Separate fact patterns were provided for disputes that students would attempt to resolve through blind-bid automated negotiation, text-based negotiation, and video mediation. Many participants would participate in the role of a disputant rather than

83 See Osgoode Hall Law School, online: <http://www.osgoode.yorku.ca/>. Students in the Osgoode Law School's Legal Information Technology Class were required to participate in the ODR simulation.

84 See Faculty of Law, University of Victoria, online: <http://www.uvic.ca/law/>. Students in the University of Victoria Law Faculty's Legal Information Technology Class were required to participate in the ODR simulation.

85 See Leicester Law School, online: <http://www2.le.ac.uk/departments/law>. Students from Leicester University were invited to participate, thanks in a large part to Pablo Cortes, who is a professor of that institution.

86 See Property Assessment Appeal Board, online: <http://www.assessmentappeal.bc.ca/>. Representatives from the Property Assessment Appeal Board volunteered to participate.

87 See British Columbia, online: $<$ http://www2.gov.bc.ca/ $>$. Representatives from the BC government volunteered to participate.

88 The number of disputes varied through the course of the project. For the third dispute resolution exercise, our records show we were tracking nineteen disputes. 
as a lawyer acting on behalf of a client. To heighten the realism for students, we avoided creating disputant pairings of students from the same university.

Law students in Osgoode Hall Law School's Mediation Intensive Program played a dual role as ODR administrators and neutrals or mediators. In the blind-bid phase, these clinical students played relatively passive administrative roles. Many of them became more involved as facilitators or mediators in the textbased negotiation phase. A third, video-conferencing phase would give them a chance to play online mediators. This inclusion of online mediation would give students a chance to experience mediation in a relatively convenient way from the place of their choosing at a mutually agreeable time. Aside from the technological aspect, it is likely that very few students - particularly those who do not engage in dedicated mediation training - would have a chance to participate directly in an alternative dispute resolution process of this type in law school.

In advance of the simulation start date, we met with Osgoode's Mediation Intensive Program students for an overview and orientation session. We also provided them with a guide explaining their tasks in each phase of the simulation (Figure 2). A question-and-answer survey was also created that would be offered to students on the conclusion of the simulation. The survey was intended to collect feedback on the experience from the participants.

\section{INSTRUCTIONS FOR BLIND BIDDING}

The Blind Bid Master folder has a bunch of subfolders in it. The subfolder numbers correspond with the numbers on the ODR Participants list. Each subfolder contains:

1. A document with an overview and the confidential instructions for each disputant

2. Google Forms that will be completed by each of the disputants. If I created everything right, the instructions for each participant should have a url to each form right in the text. They should be able to just click it and be taken to the form.

3. Each form has its own spreadsheet where the participants' answers will be recorded.

Suggested approach: after each party has entered its bids, go in to the spreadsheets for each dispute and see if an offer and demand overlaps (into the 'zone of settlement') in any round. If so, split the difference in the earliest round and call it a settlement. For example:

\begin{tabular}{|l|c|c|l|}
\hline & Demand & Offer & \multicolumn{1}{|c|}{ Result } \\
\hline Round 1 & $\$ 1000$ & $\$ 100$ & No settlement \\
\hline Round 2 & $\$ 600$ & $\$ 500$ & No settlement \\
\hline Round 3 & $\$ 500$ & $\$ 600$ & Settlement - split to be $\$ 550$ \\
\hline
\end{tabular}

The disputants should be notified of the outcome by email.

Figure 2: Excerpt from ODR Simulation Instruction Guide for Neutrals 


\section{Blind-bid Automated Negotiation}

The simulation began with a double blind-bid automated negotiation ODR simulation. The simplistic structure of this resolution process allowed role-playing claimants to make three rounds of "demands" and role-playing respondents to make three corresponding rounds of "offers." To simulate the blind-bid processes used by platforms such as Cybersettle, neither party would see the amounts entered by the other side. ${ }^{89}$ Where an offer and a demand overlapped, the difference would be split and the dispute declared resolved. Clinical mediation students started the blind-bid process by sending e-mails to each party with dispute fact patterns and confidential instructions, along with an invitation to enter their offer or demand in the platform. In this case, customized versions of Google Forms were used to simulate the simulated blind-bid platform (Figure 3)..$^{90}$

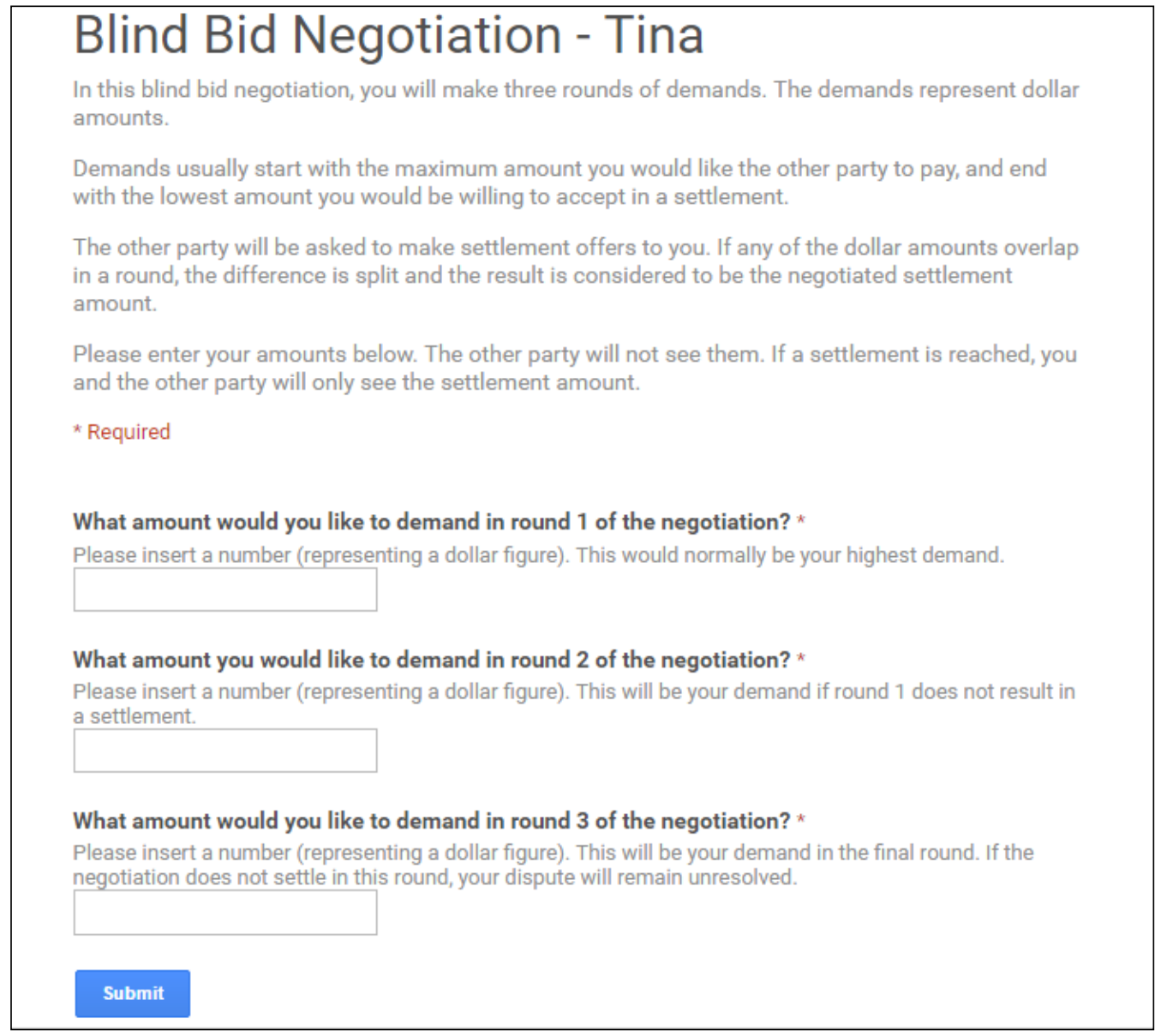

Figure 3: Screenshot of Claimant Blind-Bid Form for Simulated Claimant "Tina"

The figures entered by the role-playing disputants were exported automatically from the Google Forms into Google Sheets spreadsheets that were then manually evaluated by clinical mediation students to

89 Diane J Levin, "Cybersettle Makes the Case for Resolving Disputes Online” (2008) Mediate.com, online: $<$ http://www.mediate.com/articles/LevinDbl20080227B.cfm>.

90 See Google Forms, online: < https://www.google.ca/forms/about/>. 
identify any settlements in each of the three bid or negotiation rounds. ${ }^{91}$ The earliest round to show an overlap of demands and offers would be accepted as a settlement once the difference was split. In our simulation, six out of the total nineteen cases settled through blind-bid ODR, while ten were unable to reach agreement. The remaining three groups failed to report their results.

Students commented favourably on the expediency of the blind-bid process. ${ }^{92}$ They felt it was an efficient way to resolve disputes focused exclusively on monetary issues. Anecdotally, some students expressed frustration about being unable to talk to the other party to explain their interests or the rationale for the value of their respective offers and demands. Not only did this ODR approach inhibit interpersonal communication and interaction, but it also eliminated it by design. Students were able to engage with this concept and experience it by participating in the simulation.

\section{Text-based Negotiation}

Participants then moved to a text-based negotiation simulation. Negotiations took place on individual, web-based discussion boards. Parties were encouraged to negotiate directly with one another, although the mediation students also participated intermittently in a neutral facilitation role. This form of text-based negotiation is relatively common in ODR processes, including platforms like Juripax ${ }^{93}$ and Modria. ${ }^{94}$ It is also similar to ODR processes currently used in Canada by Consumer Protection British Columbia ${ }^{95}$ and by the British Columbia Property Assessment Appeal Board. ${ }^{96}$ Again, clinical mediation students began the process by sending e-mails to each party with dispute fact patterns, confidential instructions, and an invitation to access the online discussion board to begin negotiating. This part of the simulation used a free platform called Quick Topic (Figure 4). ${ }^{97}$ We put no restrictions on our student neutrals with respect to the timing or degree of intervention. Informally, we encouraged neutrals to let parties negotiate without any facilitation at their discretion. In the spirit of self-directed learning through experimentation, we avoided actively restricting them from intervening and facilitating at any time as well.

91 Google Sheets, online: <https://www.google.ca/sheets/about/>. Actual ODR platforms would automate this step. In our simulation, we asked administrators to do it manually because we were not using a commercial off-the-shelf platform.

92 Informal discussions with students in the Legal Information Technology courses at the Osgoode Law School and the University of Victoria Faculty of Law who served as disputants.

93 See Juripax, online: <http://www.juripax.com/> (recently acquired by Modria).

94 See Modria, online: $<$ http://modria.com/>.

95 See Consumer Protection BC, online: $<$ http://www.consumerprotectionbc.ca/odr $>$.

96 See online: <http://www.assessmentappeal.bc.ca/SubmitAnAppeal/ODRMoreDetails.asp $>$.

97 See Quick Topic, online: <http://www.quicktopic.com/>. 


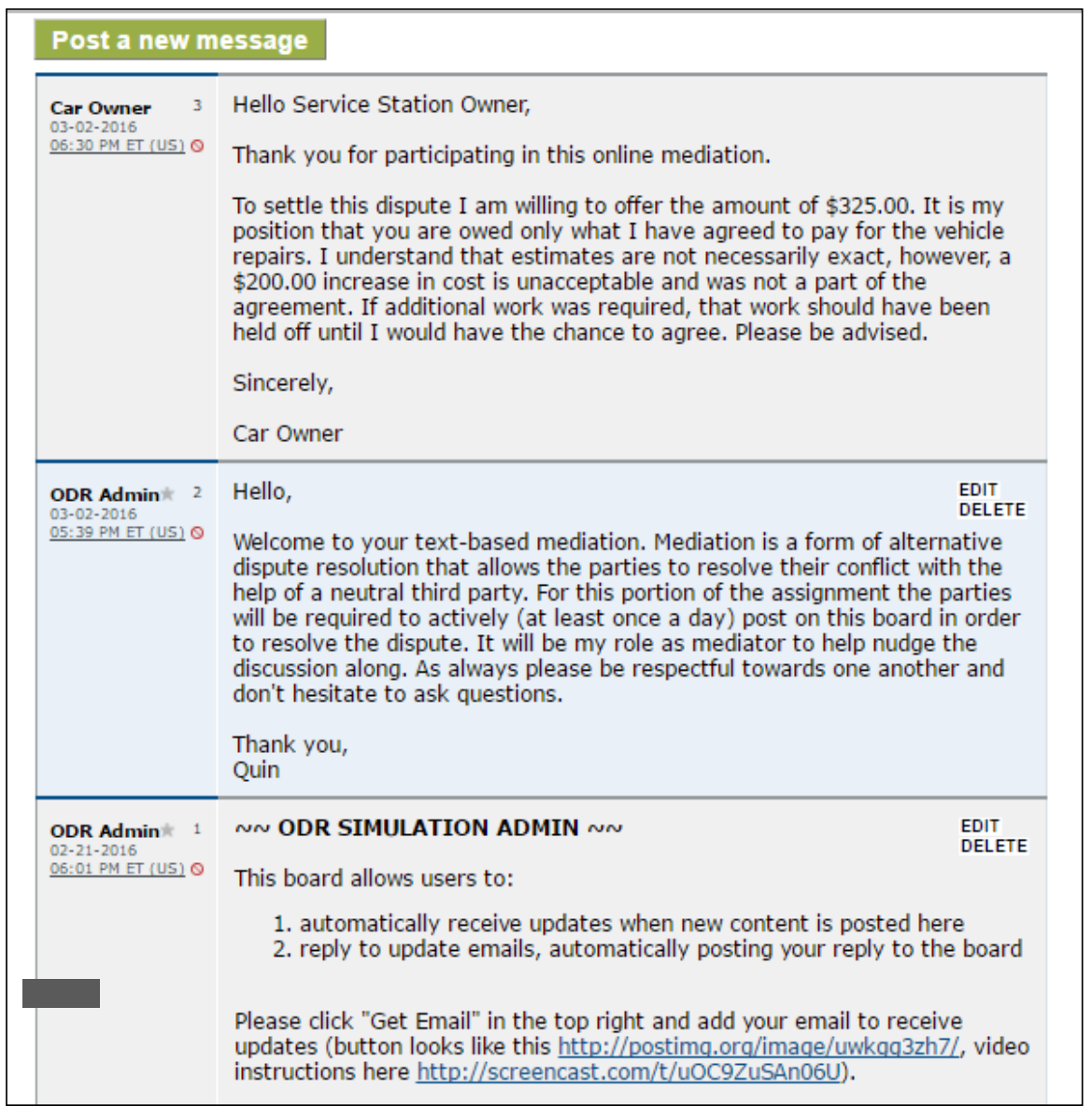

Figure 4: Screenshot of an Online Text-based Negotiation ${ }^{98}$

In our simulation, eight of the nineteen cases settled through text-based negotiation, while three were unable to reach an agreement in the discussion forum. The remaining eight groups did not report their results. The students' most common complaint about text-based negotiation related to difficulty maintaining momentum since parties responded at their leisure rather than fostering and maintaining momentum in their exchanges. ${ }^{99}$ Students also observed that longer periods of inactivity between communications often caused them to interpret the delay as an expression of frustration or negotiation tactics on the part of an opponent party, even when there may have been little basis making such inferences. As process designers, we recognized that this drawback could be mitigated by setting a time period within which parties would be required to engage in negotiations, similar to rules of procedure in arbitrations or court and tribunal processes.

\section{Video Mediation}

The final simulation exercise consisted of a video-based mediation. Most participants reportedly used Skype. Mediators facilitated a collaborative process between parties aimed at resolving disputes by

98 This screenshot was captured from the 2016 simulation.

99 Seminar-style discussions facilitated by Darin Thompson with Osgoode Law School and University of Victoria Faculty of Law students in the Legal Information Technology courses between February and March 2015 in Toronto and Victoria, Canada. 
agreement. Here again, there was a deliberate attempt to let the neutrals structure the actual ODR processes according to their preferences. As the process designers, we refrained from imposing detailed rules and requirements. In our simulation, five out of the nineteen cases settled through ODR by video conferencing, while twelve cases remained incomplete or unreported. The high numbers of incomplete disputes could result from the difficulty of scheduling a real-time interaction when all three participants were available, especially since the neutrals were in the North American eastern standard time zone, while disputants could be located in the Pacific standard time zone or in England on Greenwich mean time. ${ }^{100}$ In addition, some students reported that technical issues made video mediations difficult. Only two of the attempted nineteen cases were reported to have terminated without an agreement. Thus, the majority were just left incomplete. Anecdotally, the students who did participate as disputants in this process shared positive feedback about the facilitation guidance and the support provided by the students who served as their mediator neutrals.

\section{Post-Project Activities}

After the conclusion of the simulation, we worked with the administrators to collect statistics and communicate them to the participants through e-mail. We also created an infographic with information about the simulation that was posted on a blog post. ${ }^{101}$ This information was also shared through social media (Figure 5). ${ }^{102}$

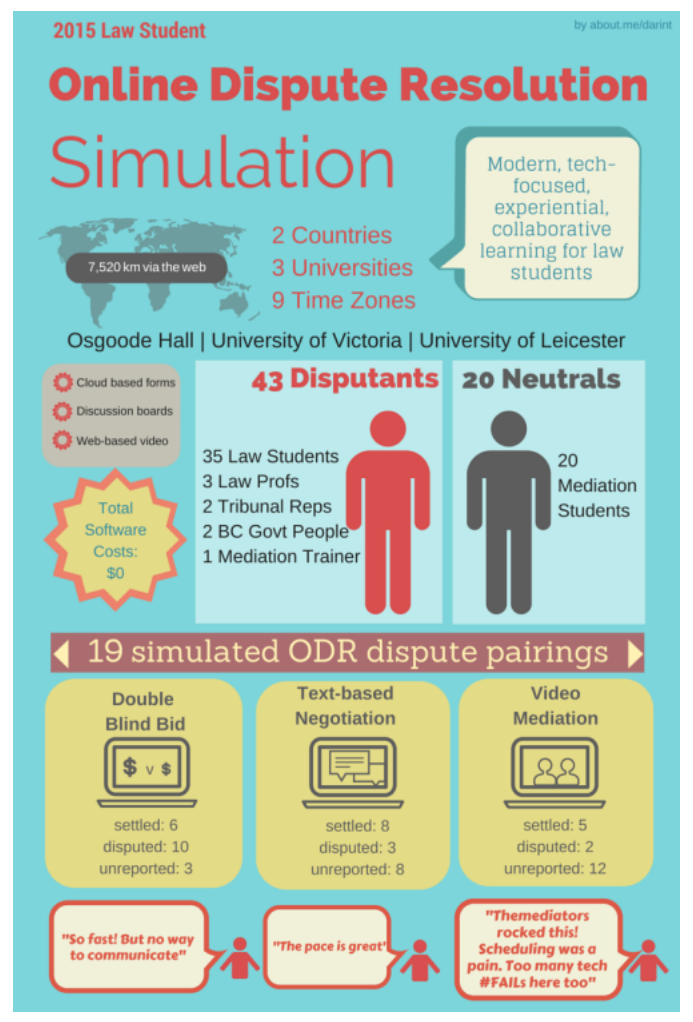

100 Because of the time zone differences, we attempted to avoid pairing role-playing disputants from the west coast of North America with disputants in England, often using the Toronto students as a mid-point in terms of matching time zones.

101 "Law Student ODR Simulation" (18 April 2015), online: https://winklerinstitute.ca/law-student-odr-simulation/

102 See eg, "How \#LegalIT \& @Osgoode MC Students Used Tech to Collaborate \& Resolve Disputes" (18 April 2015), online: <https://twitter.com/lawteched/status/589522546589966336>. 
Figure 5: Infographic Summarizing ODR Simulation Results

\section{B. Observations an Insights Gained from the ODR Simulation}

The 2015 Law Student ODR Project offered a collaborative, experiential learning opportunity for people who were generally strangers to one another and who spanned a geographical distance of 7,520 kilometres. The clinical mediation students in Toronto administered an activity that engaged students from British Columbia and England. The simulation also brought together people from three separate law schools, creating a rare type of cooperative experience in the law school curriculum (Figure 6).

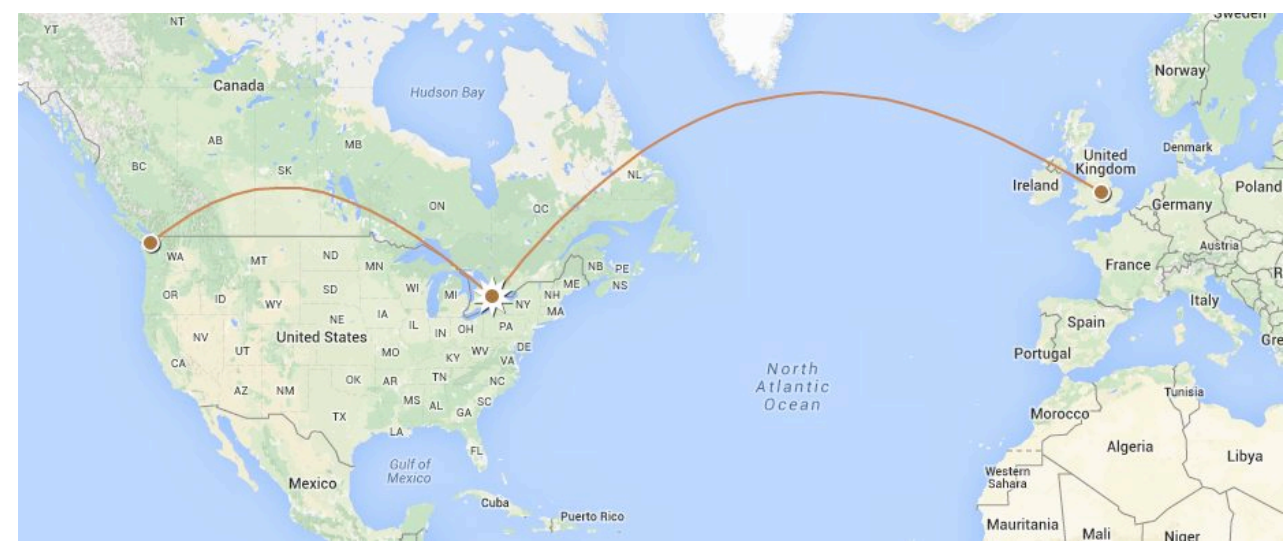

Figure 6: Technology-facilitated Collaborative Learning across 7,520 Kilometres

While we found the settlement rates to be interesting, it was never our intent to make them the subject of the simulation or a focus of learning for students. Accordingly, they should not be relied on to suggest the efficacy of ODR as a resolution practice. We put little effort into creating fact patterns that would strike a balance between either easy or difficult disputes. At times, we deliberately provided limited information to participants about the process to encourage "learning by discovery." Similarly, we did not provide extensive training or preparation in ODR for Osgoode's Mediation Intensive Program students. Lastly, we refrained from pressuring student "disputants" to actually engage in the simulation in their individual dispute pairings. Accordingly, the non-participation rate was relatively high, especially for the video mediations.

The students uncovered a range of benefits and drawbacks associated with technology-facilitated resolution. Many participants recognized the simplicity inherent in the double blind-bid process in terms of efficiency and time savings as well as its challenges with respect to communication. Participants seemed generally positive about the asynchronous text-based negotiation but tended to characterize it as being slightly inferior to a real-time video supported by an active mediator, at least with respect to the richness and pace of communications.

At minimum, this collection of experiences for the students satisfied our broadest aims to expose students to ODR and to provide hands-on experience and a basis from which to form their opinions on technology and dispute resolution. As technology becomes a more common element in access-to-justice efforts, we hope these future lawyers will draw on their experiences as students to engage in a knowledgeable way. Similarly, we were satisfied that students had the chance to experience a dispute resolution process from the perspective of the affected party. We are confident that this hand-on learning 
will enhance the perspective of the students and help them empathize with the interests and behaviours of their future clients, which could, in turn, enhance access to justice.

The pilot project's clinical mediation student administrators learned that running an ODR simulation involves a lot of effort and that managing their disputants, even for basic things like participation or scheduling, can require considerable time and effort independent of the dispute itself. Alongside the student administrators, we discovered some vexing technical issues. Well into the simulation, we learned that none of the e-mails sent from Osgoode Hall Law School's web domain were making it through to the Leicester University domain. After some frustrating one-way communication, we realized the messages were neither bouncing back nor being filtered into junk e-mail folders; they simply disappeared without notice to either the sender or the recipients. In an actual ODR process, this type of technical failure could lead to serious consequences, particularly if the process were bound by timelines or deadlines set out in the rules of procedure.

One area of the ODR simulation that brought some particular challenges was a lack of student participation. In some cases, students who volunteered to participate did not engage in a timely way. In other cases, students appeared to not participate at all. At least two of the groups of participants risked a minor deduction in their course grades for not participating. Students whose participation was completely voluntary had less incentive to participate in the simulation. One potential improvement in this area could involve the creation of more definite timelines and consequences for delay or non-participation in the ODR process. Steps could also be taken to remind students that in a digital environment they may not be as "anonymous" as they might think; our administrators could track a lack of activity with relative ease. Of course, some students claimed they were too busy to participate, ${ }^{103}$ even though we had attempted to limit the total participation time to approximately two to three hours overall for each participant and as little as thirty minutes for the blind-bid and text-based negotiation phases. Of course, these busy students were welcome to participate from any location, including their mobile phones.

From a general educational standpoint, we are satisfied that all of the participants were indeed able to gain some experience with ODR in their various roles as participants, mediators, or administrators. Instead of being a largely abstract topic of interest, ODR became something tangible through participation in experiential learning. We repeated the ODR simulation in 2016 with our Osgoode students and a range of new participants from Canada, England, and the United States. At the time of writing, the results of this simulation are still under analysis.

\section{Reflections on the ODR Simulation in the Context of Legal Education}

This simulation offered a chance for students to experience dispute resolution in an alternative dispute resolution process, which is significant considering that only 1-2 percent of civil cases filed with the courts will ultimately be resolved in a trial. ${ }^{104}$ If 98 percent of filed cases will resolve outside the courtroom, and many more will never enter the court system at all, why would we not take the opportunity to prepare students for the realities of practice? Moreover, it gave clinical mediation students a chance to

103 At least one student admitted that he was unable to participate even though he had a full week off classes for reading week. Most of the simulation could be completed on a smartphone without the need for any real research or effort. Psychologically, it may have nevertheless carried the stigma of schoolwork and therefore apparently seemed burdensome.

104 For Canadian civil trial rates, see, eg, Canadian Centre for Justice Statistics, Civil Courts Study Report (Ottawa: Minister of Industry, 1999) at 10. See also British Columbia Justice Reform Working Group, "Effective and Affordable Civil Justice," Report of the Civil Justice Reform Working Group to the Justice Review Task Force (2006) at n 3, online: http://www2.gov.bc.ca/assets/gov/law-crime-and-justice/about-bc-justice-system/justice-reforminitiatives/cjrwg_report_11_06.pdf 
practise mediation from a neutral's perspective in a modern and innovative way. While ODR was the focus, exposure to new avenues for access to justice invariably became an underlying theme of the pilot project based on the simulation.

Rather than require students to read articles or texts about the benefits and drawbacks of a subject like ODR and then ask them to formulate positions based on the opinions of others, the simulation provided an opportunity for experiential learning in a controlled learning environment. By design, the simulation put both technology and dispute resolution under analysis. In terms of law school education, we were satisfied that the ODR simulation afforded students an opportunity to look to the future of legal practice and dispute resolution rather than focus predominantly on the past, as is so often the case in legal pedagogy. We take no issue with the study of precedents or a historically grounded approach to law and dispute resolution. Indeed, we completely understand its importance. We are, however, committed to the idea that we can prepare students for the future by occasional departures from the study of the past. In this regard, pilot projects like the ODR simulation should take their place as a complementary, rather than contradictory, component of legal education. Students must study our legal past. But they also deserve training that will empower them to shape our future.

For a host or reasons beyond the scope of this article, lawyers and other dispute resolution professionals continue to be slow to adopt technologies that have been exploited by other professions and industries. The simulation was a chance to encourage students to try basic technologies that are still in the early stages of adoption for law and dispute resolution. It could inspire our next generation of lawyers to look for potential innovations that are often easily within reach. Because it is this new generation who may hold the key to address some of our current challenges around affordability, access to justice, and justice system sustainability, it is imperative as educators that we put them in the best position to lead and succeed in tomorrow's legal practice. Besides, if students do not have the chance to try potentially experimental approaches to justice and dispute resolution in university, when might they next have the chance to do so?

The requirement to collaborate with other law schools, across large distances, multiple time zones, and continents was consistent with the experimental and experiential thrusts of the pilot project focused on ODR. The simulation gave participants in multiple universities and jurisdictions an opportunity to interact, and, indeed, to learn, together. Clinical mediation students gained the chance to apply their skills in a cross-jurisdictional, international environment, enabled by modern technologies that many lawyers and other justice professionals have not yet adopted in practice.

\section{CONCLUSION AND FUTURE DIRECTIONS}

What directions could this exercise take in the future? As a starting point, we believe the ODR simulation, or a variation of it, is worth repeating. In terms of technology, the simulation could be improved by using dedicated ODR platforms to increase the realism for participants and to reduce the learning curve for administrators. This burden on administrators could also be shifted substantially onto a single person or role, letting the clinical mediation students who served as neutrals focus more on dispute resolution and less on the mechanics of the improvised technology. To boost participation levels, future experiments could benefit from clearer expectations for student participants. Consequences could also be set for non-participation. Rules of procedure could set out timelines, required actions, and consequences for non-compliance within each of the various ODR phases.

In terms of research, the ODR simulation could be formally evaluated, analyzed, or critiqued along with other forms of experiential legal education. Cross-disciplinary research opportunities could be explored in terms of the behaviour of students interacting through technology or the economics of decision making in processes like blind bidding. Some researchers might also see the potential for ethical 
explorations and experiments around ODR or dispute resolution generally, using the virtual classroom as a laboratory environment. On a much broader level, further investigation and study into the benefits or drawbacks of collaboration between students in different law schools and different jurisdictions could be undertaken.

In the course of describing the ODR simulation, this article has also outlined the practice of ODR and has summarized some of its benefits and drawbacks. We have explained how this pilot project provided students with the opportunity to understand issues around technology and dispute resolution as well as access to justice. Our role as legal educators should be to prepare students for the legal field they will encounter rather than the one that used to exist. While it may seem unbelievable now, Richard Susskind's suggestion in his 1996 book The Future of Law that e-mail would become the primary mode of communication between lawyers and clients was heralded as heresy. ${ }^{105}$ Times are changing. David Larson posits that the next generation

will not be asking how technology can enhance existing dispute resolution practices and models because they will be comfortable using technology to communicate, they instead will want to know what dispute resolution processes they can use in the virtual spaces where they live. They will be searching for dispute resolution processes to complement their technology, not technology to complement their dispute resolution models and practices. ${ }^{106}$

ODR is one approach for using technology in a new, innovative way to resolve disputes and improve access to justice. In our pilot project, participants were invited to experience it in the course of their legal education on the way to becoming tomorrow's lawyers.

105 Richard Susskind, The Future of Law: Facing the Challenges of Information Technology (Oxford: Clarendon Press, 1996).

106 David Allen Larson, "Technology Mediated Dispute Resolution (TMDR): A New Paradigm for ADR” (2006) 21:3 Ohio St J Disp Resol 631. 